\title{
Pengaruh Poliherbal Ekstrak Jeringau, Temu Mangga Dan Bawang Putih Pada Fungsi Hepar Tikus (Rattus norwegicus)
}

\author{
Bayyinatul Muchtaromah ${ }^{1}$, Rahmi Annisa ${ }^{2}$, Sofiyah ${ }^{3}$ \\ ${ }^{1,3}$ Jurusan Biologi, Fakultas Sains dan Teknologi Universitas Islam Negeri \\ Maulana Malik Ibrahim Malang, Indonesia \\ ${ }^{2}$ Jurusan Farmasi Fakultas Kedokteran dan Ilmu Kesehatan Universitas Islam Negeri \\ Maulana Malik Ibrahim Malang, Indonesia \\ ${ }^{1}$ Email: bayyinatul@bio.uin-malang.ac.id
}

\begin{abstract}
Abstrak: Penelitian ini bertujuan untuk mengetahui pengaruh pemberian poliherbal ekstrak jeringau (Acorus calamus), temu mangga (Curcuma mangga), dan bawang putih (Allium sativum) terhadap kadar enzim Glutamat Oksaloasetat Transaminase (GOT) dan Glutamat Piruvat Transaminase (GPT) hepar tikus putih. Hasil penelitian ini dapat digunakan sebagai indikator terhadap keamanan penggunaan obat berbahan alam terhadap tubuh. Penelitian ini menggunakan rancangan acak lengkap (RAL) dengan 9 perlakuan dan 3 ulangan. Perlakuan terdiri atas K- (tanpa perlakuan), K+ (klomifen sitrat dosis 0,9 mg/kg BB), P1 (kombinasi 1 dosis $50 \mathrm{mg} / \mathrm{kgBB}$, P2 (kombinasi 1 dengan dosis $75 \mathrm{mg} / \mathrm{kgBB}$ ), P3 (kombinasi 1 dengan dosis $100 \mathrm{mg} / \mathrm{kgBB}$ ), P4 (kombinasi 2 dengan dosis $50 \mathrm{mg} / \mathrm{kgBB}$ ), P5 (kombinasi 2 dengan dosis $75 \mathrm{mg} / \mathrm{kgBB}$ ), P6 (kombinasi 2 dengan dosis $100 \mathrm{mg} / \mathrm{kgBB}$ ), P7 (jamu subur kandungan dengan dosis $75 \mathrm{mg} / \mathrm{kgBB}$ ). Hasil penelitian menunjukkan kadar enzim GPT tertinggi ditemukan pada kelompok perlakuan 3 dengan pemberian ekstrak kombinasi 1 dengan dosis $100 \mathrm{mg} / \mathrm{kgBB}$ sebesar 46,7 U/L dan kadar terendah pada P7 14,4 U/L, sedangkan kadar enzim GOT tertinggi terdapat pada P6 yaitu 57,6 U/L dan terendah pada P4 23.3 U/L. Hasil kadar kedua enzim transaminase tersebut masih dalam kategori normal.
\end{abstract}

Kata Kunci: Jeringau, Temu Mangga, Bawang Putih, Hepar, GPT, GOT

\begin{abstract}
This study aims to determine the effect of polyherbal extract of jeringau (Acorus calamus), temu mangga (Curcuma mangga), and garlic (Allium sativum) on the levels of Glutamate Oxaloacetate Transaminase (GOT) and Glutamate Pyruvate Transaminase (GPT) enzymes in rat hepar. The results of this study can be used as an indicator of the safety of using natural-based drugs on the body. This study used a completely randomized design (CRD) with 9 treatments and 3 replications. Treatment consists of K- (without treatment), $\mathrm{K}+$ (clomiphene citrate dose of $0.9 \mathrm{mg} / \mathrm{kg} \mathrm{BW}$ ), P1 (combination 1 at dose $50 \mathrm{mg} / \mathrm{kgBB}, \mathrm{P} 2$ (combination 1 at a dose of $75 \mathrm{mg} / \mathrm{kgBB}$ ), P3 (combination 1 at a dose of $100 \mathrm{mg} / \mathrm{kgBB}, \mathrm{P} 4$ (combination 2 at a dose of $50 \mathrm{mg} / \mathrm{kgBB}$ ), P5 (combination 2 at a dose of $75 \mathrm{mg} / \mathrm{kgBB}$ ), P6 (combination 2 at a dose of 100
\end{abstract}


$\mathrm{mg} / \mathrm{kgBB}$ ), P7 (Subur kandungan herb at dose of $75 \mathrm{mg} / \mathrm{kgBB}$ ). The results showed the highest levels of GPT enzymes were found in the treatment group 3 with the administration of combination 1 extract with a dose of $100 \mathrm{mg} / \mathrm{kg} \mathrm{BW}$ of $46.7 \mathrm{U} / \mathrm{L}$ and the lowest level at P7 14.4 U / L, while the highest GOT enzyme levels were found in P6 namely 57.6 U / L and the lowest at P4 23.3 U / L. The results of the levels of the two transaminase enzymes are still in the normal category.

Keywords: Jeringau, Temu Mangga, Garlic, Hepar, GPT, GOT

Masyarakat Indonesia telah lama mengenal dan menggunakan tanaman berkhasiat obat sebagai salah satu upaya dalam menanggulangi masalah kesehatan. Pengetahuan tentang tanaman berkhasiat obat berdasar pada pengalaman dan keterampilan yang secara turun temurun telah diwariskan dari satu generasi ke generasi berikutnya. Selain itu, obat tradisional telah diterima secara luas di hampir seluruh negara di dunia (Sari, 2006). WHO telah merekomendasi penggunaan obat tradisional dalam pemeliharaan kesehatan masyarakat, pencegahan dan pengobatan penyakit, dan WHO juga mendukung upayaupaya dalam peningkatan keamanan dan khasiat dari obat tradisional (Sukandar, 2006).

Khasiat obat tradisional telah banyak dibuktikan, salah satunya yaitu ramuan Madura untuk mengatasi masalah kesuburan wanita (Mudjijono, 2014). Jamu Subur Kandungan yang diproduksi oleh PJ. Ribkah Maryam Jokotole dari kabupaten Bangkalan Madura memiliki komposisi rimpang jeringau (Curcuma mangga. Val.) (15\%), rimpang temu mangga (Acorus calamus, L.) (12\%), dan umbi bawang putih (Alium sativum, Linn.) (15\%) dan bahan lain hingga 100\%. Adapun khasiat dari jamu tersebut sesuai dengan yang tertera di kemasan antara lain berfungsi untuk memperkuat otot-otot rahim, menyuburkan kandungan, menyehatkan badan dan kandungan serta mencegah keguguran.

Kandungan bahan aktif rimpang jeringau antara lain : minyak atsiri, glukosida acorin, acoretin, calamin, calamenenol, cholin, tannin, sesquisterpen, terpenoid, flavanoid dan alkaloid (Hendrajaya, 2003). Berdasarkan hasil uji fitokimia secara kualitatif pada ekstrak etanol rimpang jeringau positif mengandung senyawa golongan alkaloid dan triterpenoid (Muchtaromah, et al., 2017). Kandungan saponin, flavonoid dan alkaloid berfungsi sebagai hepatoprotektor, sedangkan triterpenoid atau steroid merupakan senyawa yang memiliki peranan sebagai antioksidan (Lengkong, 2013). Mikroba patogen dan radikal bebas juga dapat menyebabkan infertilitas, sehingga senyawa antioksidan diperlukan dalam menetralkan radikal bebas tersebut. Dalam penelitian sebelumnya, senyawa aktif yang dapat digunakan sebagai antioksidan dan juga terkandung dalam ekstrak etanol rimpang jeringau adalah alkaloid dan triterpenoid (Muchtaromah, et al., 2017). Ekstrak etanol memiliki aktivitas antioksidan tertinggi yang dapat disebabkan oleh zat aktif dari beberapa senyawa antioksidan yang terkandung di dalamnya. Penelitian sebelumnya membuktikan bahwa rimpang jeringau yang diekstraksi 
dengan etanol memiliki kelompok senyawa antioksidan seperti alkaloid dan triterpenoid (Muchtaromah, et al., 2018)

Kandungan kimia pada ekstrak jeringau (A. calamus), rimpang temu mangga ( $C$. mangga) dan umbi bawang putih (A. sativum) yaitu senyawa flavonoid, alkaloid, triterpenoid, saponin, minyak atsiri dimana efektif sebagai hepatoprotektor namun jika penggunaan dalam jangka panjang perlu penelitian lebih lanjut (Staden, 2002).

Penelitian ini dilakukan untuk mengetahui keamanan dan efek toksik terhadap hepar sebagai salah satu organ yang berfungsi dalam metabolisme obat dan zat kimia. Sehubungan dengan cara penggunaan obat yang relatif lama dan kemungkinan adanya efek akumulasi obat, maka perlu dilakukan uji untuk melihat pengaruh pemberian poliherbal ekstrak rimpang jeringau, rimpang temu mangga dan umbi bawang putih pada tikus putih (Rattus norvegicus).

\section{METODE PENELITIAN}

Simplisia rimpang jeringau, rimpang temu mangga dan umbi bawang putih (Materia Medika Batu), jamu subur kandungan (produksi PJ. Ribkah Maryam Jokotole), etanol (Smartlab) Na CMC (Himedia), Cisplatin (Dankos), hormon PMSG (Intervet), hormon hCG (Intervet), klomifen sitrat (Sande Farma), pewarna giemsa (Sigma), bahan kimia yang lain yaitu kloroform, alkohol $70 \%$, PBS, Reagen kit GOT dan GPT (Glory Diagnostic).

\section{Ekstraksi rimpang jeringau, temu mangga dan umbi bawang putih}

Prosentase bahan penyusun ekstrak jeringau, temu mangga dan bawang putih terdapat pada tabel berikut ini:

Tabel 1. Komposisi Herbal

\begin{tabular}{l|c|c|c}
\hline \multirow{2}{*}{ Kombinasi } & \multicolumn{3}{|c}{ Presentase (\%) Bahan Penyusun } \\
\cline { 2 - 4 } & Jeringau & Temu Mangga & Bawang Putih \\
\hline Kombinasi 1 & 28 & 36 & 36 \\
Kombinasi 2 & 25 & 40 & 35 \\
\hline
\end{tabular}

Bahan penyusun ekstrak yang telah ditimbang, dicampur dan ditambahkan pelarut etanol 70\% sebanyak $300 \mathrm{ml}$, kemudian direndam selama 24 jam. Kemudian disaring dengan kertas saring Whattman dan ampas yang diperoleh dimaserasi kembali dengan etanol $70 \%$. Tahap tersebut dilakukan sebanyak 2 kali ulangan sampai filtratnya berwarna bening. Filtrat hasil maserasi dipekatkan dangan rotary evaporator pada suhu $50^{\circ} \mathrm{C}$ sampai didapatkan ekstrak pekat.

\section{Penyerentakan Siklus Estrus}

Proses penyerentakan siklus estrus dilakukan dengan cara injeksi HCG (Human Chorionic Gonadotropin) dan PMSG (Pregnant Mare Serum Gonadotropin) 10 IU. Hormon HCG dan PMSG IU diberikan kepada tikus masing-masing 0,2 ml. PMSG 
diberikan 48 jam setelah pemberian HCG dan diberikan selang dua hari setelah dilakukan aklimatisasi (Byers, et al., (2012).

\section{Penentuan Siklus Estrus Menggunakan Apusan Vagina}

Penentuan siklus estrus diawali dengan membuat preparat apusan vagina yang dilakukan setiap hari pada pukul 09.00-11.00 WIB. Penggambilan sampel dilakukan dengan menggunakan cotton bud yang dibasahi dengan larutan $\mathrm{NaCl}$, lalu dimasukkan ke dalam vagina tikus betina dengan sudut $\pm 45^{\circ}$ dan diulas sebanyak 1-2 kali putaran. Hasil dioleskan pada gelas objek dan dikeringkan pada suhu kamar. Setelah kering, apus vagina dimasukkan ke dalam larutan etanol 10\% untuk difiksasi selama 3 menit, kemudian diangkat, dicuci dengan air mengalir dan dikeringkan. Apusan vagina dimasukkan ke dalam larutan giemsa selama 15 menit lalu diangkat dan dibilas dengan air yang mengalir dan dikeringkan (Sjahfirdi, 2013). Preparat apusan vagina kemudian diamati menggunakan mikroskop cahaya dengan perbesaran 10x dan 40x.

\section{Pemberian Perlakuan dan Pembedahan}

Poliherbal ekstrak diberikan pada tikus putih betina fertil secara oral. Pemberian ekstrak kombinasi dilakukan setiap hari pada pukul 09.00 pagi selama 15 hari atau selama 3 kali siklus estrus. Penelitian ini menggunakan 9 kelompok perlakuan, masing-masing kelompok terdiri dari 3 ekor tikus putih sebagai ulangan. Kelompok perlakuan dibagi sebagai berikut: $\mathrm{K}-: 0,5 \mathrm{ml} \mathrm{Na} \mathrm{CMC} 0,5 \%$; $\mathrm{K}+:$ Klomifen sitrat dosis $0,9 \mathrm{mg} / \mathrm{kgBB}+$ 0,5 ml NaCMC 0,5\%; P1 : Kombinasi 1 dosis $50 \mathrm{mg} / \mathrm{kg} \mathrm{BB}+0,5 \mathrm{ml} \mathrm{Na}$ CMC 0,5\%; P2 : Kombinasi 1 dosis 75 mg/kg BB + 0,5 ml Na CMC 0,5\%; P3 : Kombinasi 1 dosis 100 $\mathrm{mg} / \mathrm{kg} \mathrm{BB}+0,5 \mathrm{ml} \mathrm{NaCMC} \mathrm{0,5 \%}$; P4 : Kombinasi 2 dosis $50 \mathrm{mg} / \mathrm{kg} \mathrm{BB}+0,5 \mathrm{ml} \mathrm{Na}$ CMC 0,5\%; P5 : Kombinasi 2 dosis $75 \mathrm{mg} / \mathrm{Kg} \mathrm{BB}+0,5 \mathrm{ml} \mathrm{Na} \mathrm{CMC} 0,5 \%$; P6 : Kombinasi 2 dosis $100 \mathrm{mg} / \mathrm{Kg} \mathrm{BB}+0,5 \mathrm{ml} \mathrm{Na}$ CMC 0,5\%; P7 : Jamu subur kandungan dosis $75 \mathrm{mg} / \mathrm{Kg} \mathrm{BB}+0,5 \mathrm{ml} \mathrm{Na} \mathrm{CMC} 0,5 \%$. Pada akhir penelitian hewan coba dikorbankan, dilakukan pembedahan dan diambil organ hepar untuk uji kadar GOT dan GPT.

\section{Pengukuran Kadar GOT dan GPT}

Pengukuran kadar enzim GOT dan GPT pada dasarnya sama hanya terdapat perbedaan pada reagen yang digunakan. Pertama-tama diambil organ hati dan dicuci dengan larutan NaCL $0,9 \%$, kemudian ditimbang $200 \mathrm{~g}$ organ hati dan digerus hingga diperoleh cairan kental, lalu diambil cairan kental sebanyak $200 \mathrm{mg}$ dan diencerkan dengan larutan PBS sebanyak 200 mikrolit 1 kali pengulangan dengan perbandingan 1:1 (200:200), disentrifuge filtrat dengan kecepatan $1.000 \mathrm{rpm}$ selama 5 menit, diambil 50 mikrolit supernatan dan dimasukkan ke dalam kuvet, diambil pereaksi GPT (reagen 1, reagen 2) dan GOT (reagen 1, reagen 2) dengan perbandingan 4: 1 sebanyak $1 \mathrm{ml}$, dihomogenkan R1 dan R2. Reagen dan sampel diinkubasi dengan suhu $37^{\circ} \mathrm{C}$ selama 15 menit, dimasukkan reagen campuran 1 dan 2 ke dalam sampel kuvet sebanyak $1 \mathrm{ml}$ di inkubator agar suhu tetap stabil dan ditambahkan 50 mikrolit sampel dan dihomogenkan, 
disentrifuge dengan kecepatan 1.000 RPM selama 5 menit lagi untuk memisahkan antara pelet dan supernatan, spektrofotometri dengan panjang gelombang $340 \mathrm{~nm}$ dan melihat nilai absorbansi setiap 1 menit selama 3 menit (3 kali). Perhitungannya dilakukan dengan rumus: GPT $\mathrm{U} / \mathrm{L}=\Delta \mathrm{a} / \min \times 3333\left(37^{\circ} \mathrm{C}\right)$ (Pathak, et al., 2016)

Data yang diperoleh dianalisis terlebih dahulu dengan uji normalitas KolmogrovSmirnov dan uji homogenitas Levene. Apabila data sudah homogen dan terdistribusi normal maka dilanjutkan dengan uji parametrik Sidik Ragam (Analysis of variance) a 5 $\%$, jika tidak terdistribusi normal atau tidak homogen maka dilakukan analisis alternative Brown Forsythe test. Jika hasil uji Sidik Ragam menunjukkan ada pengaruh yang signifikan, maka dilanjutkan dengan uji lanjut Beda Nyata Terkecil (Least Significance Different) BNT dengan signifikansi $\alpha=5 \%$.

\section{HASIL DAN PEMBAHASAN}

Hasil penelitian menunjukkan bahwa data rata-rata kadar enzim GPT tertinggi dihasilkan oleh P3 dan P6 selanjutnya diikuti oleh P2, P1, kemudian P5, K-, K+, P4 dan kadar terendah ditemukan pada P7. Berdasarkan uji non parametrik (Brown Forsthy Test) menunjukkan bahwa data pemberian ekstrak etanol rimpang jeringau, bawang putih dan temu mangga tidak memberikan pengaruh yang signifikan atau tidak berbeda nyata terhadap kadar GPT hepar tikus putih betina. Nilai rata-rata kadar enzim GPT hepar tikus setelah diberikan ekstrak jeringau, temu mangga dan bawang putih dapat dilihat pada Tabel 2.

Tabel 2. Nilai rata-rata kadar enzim GPT hepar tikus setelah diberikan ekstrak jeringau, temu mangga dan bawang putih

\begin{tabular}{l|c}
\hline \multicolumn{1}{c|}{ Kelompok Perlakuan } & Rata-rata $(\mathbf{I} / \mathbf{U}) \pm$ SD \\
\hline (K-) $=$ tanpa perlakuan & $21,1 \pm 1,1$ \\
$(\mathrm{~K}+)=$ klomifen sitrat & $17,4 \pm 2,0$ \\
$(\mathrm{P} 1)=$ kombinasi 1 & $33,3 \pm 1,9$ \\
$(\mathrm{P} 2)=$ kombinasi 1 & $34,1 \pm 6,8$ \\
$(\mathrm{P} 3)=$ kombinasi 1 & $46,6 \pm 1,7$ \\
$(\mathrm{P} 4)=$ kombinasi 2 & $16,6 \pm 3,8$ \\
$(\mathrm{P} 5)=$ kombinasi 2 & $26,6 \pm 3,8$ \\
(P6) $=$ kombinasi 2 & $34,4 \pm 2,2$ \\
(P7) $=$ jamu subur kandungan & $14,4 \pm 2,9$ \\
\hline
\end{tabular}

Nilai rata-rata kadar enzim GOT hepar tikus setelah diberikan ekstrak Acorus calamus, Curcuma mangga, dan Allium sativum dapat dilihat pada Tabel 3.

Tabel 3. Nilai rata-rata enzim GOT hepar tikus setelah diberikan ekstrak Acorus calamus, Curcuma mangga, dan Allium sativum

\begin{tabular}{l|c}
\multicolumn{1}{c|}{ Kelompok Perlakuan } & Rata-rata(I/U) \pm SD \\
\hline$(\mathrm{K}-)=$ tanpa perlakuan & $47,4 \pm 1,4$ \\
$(\mathrm{~K}+)=$ klomifen sitrat & $51,1 \pm 4,4$
\end{tabular}

BIOLOGI SEL (YOL 8 NO 1 EDISI JAN-JUN 2019 ISSN 2252-858X/E-ISSN 2541-1225) PAGE 75 


\begin{tabular}{|c|c|}
\hline$(\mathrm{P} 1)=$ kombinasi 1 & $34,4 \pm 1,2$ \\
\hline$(\mathrm{P} 2)=$ kombinasi 1 & $46,6 \pm 8,8$ \\
\hline$(\mathrm{P} 3)=$ kombinasi 1 & $47,3 \pm 1,1$ \\
\hline$(\mathrm{P} 4)=$ kombinasi 2 & $23,3 \pm 8,3$ \\
\hline$(\mathrm{P} 5)=$ kombinasi 2 & $32,2 \pm 6,1$ \\
\hline$(\mathrm{P} 6)=$ kombinasi 2 & $57,5 \pm 1,5$ \\
\hline$(P 7)=$ jamu subur kandungan & $36,4 \pm 1,5$ \\
\hline
\end{tabular}

Hasil uji statistik pada pengukuran kadar enzim GOT dengan uji ANOVA menunjukkan nilai signifikansi $>0,05$ yaitu $(0,554>0,05)$ sehingga dapat disimpulkan bahwa hipotesa $\mathrm{H} 0$ diterima dan $\mathrm{H} 1$ ditolak. Hal ini menunjukkan bahwa pemberian ekstrak etanol $70 \%$ rimpang jeringau, temu mangga dan bawang putih tidak mempengaruhi kadar enzim GOT pada hepar tikus putih (Rattus nevorgicus).

Berdasarkan penelitian sebelumnya mengatakan bahwa rentang kadar normal GPT pada hepar tikus putih adalah berkisar antara 17,5-30,2 (IU/L), sedangkan nilai normal GOT pada tikus 45,7-80,8 (IU/L) (Sagita, 2012). Berdasarkan literatur yang lain, nilai range normal GPT tikus jantan 42,9-67,4 (IU/L) dan betina 34,2-61,6 (IU/L), GOT tikus jantan 92,3-122,5 dan betina 82,7-139,6 (IU/L) (Sagita, 2012). Parameter GPT lebih spesifik dibanding GOT untuk mengetahui fungsi hepar karena enzim glutamat piruvat transaminase terdapat di hepar sedangkan enzim glutamat oksaloasetat transaminase selain terdapat di hepar juga terdapat dalam otot, jantung dan jaringan lain. Adanya kerusakan pada hepar dapat menurunkan kadar enzim tersebut di dalam hepar dan meningkatkan kadar enzim tersebut dalam serum darah. Enzim GPT berperan dalam deaminasi asam amino, pengeluaran gugus amino dari asam amino (Hayes, 2007). GPT mampu memindahkan gugus amino pada alanin ke gugus keto dari $\alpha$-ketoglutarat membentuk glutamat ke piruvat. Piruvat yang terbentuk bereaksi dengan 2,4-dinitro fenilhidrasin dalam larutan alkalis. Selanjutmya piruvat diubah menjadi laktat. Reaksi tersebut dikatalisis oleh enzim laktat dehidrogenase (LDH) yang membutuhkan NADH dalam reaksi yang dikatalisis.

Berdasarkan hasil pengukuran data GPT dan GOT pada kelompok kontrol jumlah rata-rata GPT adalah 21,1 U/L sedangkan pada GOT jumlah rata-ratanya adalah 47,4 U/L. Terjadi kenaikan nilai GPT dan GOT pada kelompok kombinasi 1 dan 2 dosis 50, 75 dan $100 \mathrm{mg} / \mathrm{kg}$ BB dengan jumlah rata-rata GPT kombinasi 1 berturut-turut adalah 33,4 U/L; 34,1 U/L, 46,7 U/L dan kombinasi 2 berturut-turut adalah 16,7 U/L; 26,7 U/L; 34,5 U/L sedangkan jumlah rata-rata GOT kombinasi 1 berturut-turut adalah 34,4 U/L ; 46,7 U/L, 47,333 U/L dan kombinasi 2 berturut-turut adalah 23,3 U/L; 32,2 U/L; 57,6 U/L. Terlihat dari data pengukuran GPT dan GOT adanya peningkatan nilai pada masing-masing perlakuan Kombinasi 1 dan 2 (dosis 50, dosis 75, dan dosis $100 \mathrm{mg} / \mathrm{kgBB}$ ) jika dibandingkan dengan kelompok kontrol. Peningkatan nilai GPT dan GOT pada masing- 
masing kelompok dosis (dosis 50, dosis 75, dan dosis $100 \mathrm{mg} / \mathrm{kgBB}$ ) secara keseluruhan belum menyimpang atau masih berada pada kisaran normal. Pada kerusakan hepar kadar GPT dan GOT akan menurun secara drastis dan akan meningkat 10-100 kali dalam serum dari nilai normal, hal ini disebabkan enzim transaminase hepar akan keluar dan masuk ke peredaran darah (Murray, 2009). Hal ini berarti pemberian ekstrak etanol kombinasi 1 dan 2 dosis 50,75 dan $100 \mathrm{mg} / \mathrm{kgBB}$ tidak mempengaruhi fungsi hepar. Hal ini dikarenakan bawang putih, temu mangga dan jeringau bersifat hepatoprotektor.

Berdasarkan penelitian ini, dosis 50 hingga $100 \mathrm{mg} / \mathrm{kg}$ BB merupakan rentang dosis yang aman untuk dikonsumsi. Hal ini disebabkan dosis tersebut memiliki kadar GPT dan GOT yang normal. Hal ini menunjukkan bahwa pemberian poliherbal tersebut memiliki efek hepatoprotektor. Hepatoprotektor merupakan senyawa berkhasiat yang melindungi sel hepar terhadap pengaruh zat toksik yang mampu merusak hepar. Senyawa tersebut dapat memperbaiki jaringan hepar yang fungsinya dalam keadaan terganggu. Mekanisme kerja obat hepatoprotektor dengan cara detoksikasi senyawa racun baik yang masuk dari luar maupun yang terbentuk di dalam tubuh melalui proses metabolisme, meningkatkan regenerasi sel hepar yang rusak, antiradang, dan sebagai imunostimulator (Dalimartha. 2005).

Kerusakan hepar disebabkan oleh gangguan keseimbangan dari ion-ion, cairan atau produk-produk metabolisme seperti lemak bebas dan hasil penguraian dari membran fosfolipid. Keadaan tersebut menyebabkan terjadinya gangguan keseimbangan cairan yang berupa pembengkakan sel maupun degenerasi seluler. Pada kasus berat dapat menyebabkan terjadinya kematian sel, yang dapat diketahui dengan adanya perubahanperubahan sitoplasma dan inti selnya (Dalimartha. 2005). Pada kasus keracunan berat menyebabkan terjadinya kegagalan fungsi hepar yang dapat menyebabkan kematian dalam $12-24$ jam. Meskipun demikian hepar merupakan organ yang dapat mempertahankan fungsinya, sehingga dapat mempertahankan fungsi normalnya meskipun dengan 10 - $12 \%$ unit fungsional yang normal (Dalimartha. 2005).

Kelainan fungsi hepar dapat disebabkan karena adanya kadar glukosa darah yang meningkat, sehingga memaksa hepar bekerja lebih keras lagi dalam proses pemecahan glikogen untuk memenuhi kebutuhan glukosa yang kurang mencukupi karena kurangnya insulin dalam tubuh. Kelainan fungsi hepar disebabkan oleh radikal bebas, sedangkan radikal bebas ini dapat diatasi oleh senyawa antioksidan. Antioksidan adalah senyawa yang mempunyai struktur molekul yang dapat memberikan elektronnya kepada molekul radikal bebas tanpa mengganggu fungsi dan dapat memutuskan reaksi berantai dari radikal bebas bahan asing yang masuk ke dalam tubuh, dimetabolisme melalui proses enzimatik sebagai pertahanan untuk melindungi tubuh dari bahan kimia berbahaya. Secara simultan, bahan berbahaya buangan tersebut dimetabolisme dan diekskresikan dalam bentuk urin yang dikeluarkan setiap hari (Dalimartha. 2005). 
Ekstrak rimpang jeringau, temu mangga dan bawang putih mempunyai kandungan kimia berupa flavonoid, alkoloid, saponin, dan minyak atsiri (Muchtaromah, et al., 2017). Alkaloid merupakan substansi kimia yang mengandung nitrogen, walaupun tidak semua nitrogen terdapat dalam alkaloid. Flavonoid dan alkaloid berfungsi sebagai antioksidan dan imunomodulator yang memproduksi molekul sitokin sebagai respon induksi akibat invasi bakteri patogen, kerusakan sel, dan regenerasi sel (Muchtaromah, et al., 2017).

Kurkumin berperan sebagai gastroprotektan dan melindungi sel hepatosit dari senyawa-senyawa yang dapat merusak sel hepatosit seperti karbon tetraklorida dan peroksida. Aktivitas kurkumin diharapkan dapat mencegah proses peradangan pada gastrointestinal dan hepar (Chattopadhyay, 2004). Temu mangga merupakan tanaman temulawak yang mengandung zat aktif kurkumin sebagai antibakteri, antifungi, antiprotozoa, antiviral, dan meningkatkan aktivitas pankreas dalam sekresi enzim tripsin dan kimotripsin. Ekstrak kurkumin dapat mencegah kerusakan hepar yang diinduksi alkohol pada tikus (Chattopadhyay, 2004). Hasil penelitian dengan menunjukkan adanya pengujian dengan enzim GOT dan GPT tersebut adalah untuk menentukan adanya suatu indikator untuk mendeteksi kerusakan hepar dengan enzim transminase namun peneliti tidak melakukan uji histologi karena secara teori enzim transminase merupakan metode paling efektif sebagai indikator kerusakan hepar berdasarkan metabolisme tubuh manusia dengan dibuktikan adanya reaksi kimia dan biokimia dalam tubuh manusia sedangkan pada histologi menandakan adanya indikator kerusakan untuk sel-sel hepar berdasarkan faktor fisiologisnya.

Perbedaan dosis yang semakin tinggi memungkinkan menjadi penyebab kerusakan hepar. Ekstrak air pegagan dosis besar menyebabkan kerusakan hepar, ginjal dan jantung (Pratiwi, 2010). Keadaan tersebut berlawanan dengan hasil penelitian yaitu tidak menyebabkan kerusakan pada organ diatas. Kemungkinan dapat terjadi ketika tanaman bentuk tunggal mempunyai sifat toksik, akan tetapi ketika dikombinasi dengan tanaman yang lain dalam bentuk ramuan efek toksiknya berkurang atau hilang. Ekstrak bawang putih sangat bernilai untuk detoksifikasi dan antioksidasi pada kadar $1 \mathrm{mM}$, namun pada kadar $5 \mathrm{mM}$ secara nyata dapat menurunkan viabilitas sel, mengubah morfologi sel, dan menurunkan aktivitasnya. Umbi bawang putih aman untuk dikonsumsi manusia pada takaran normal, yakni kurang dari tiga umbi per hari. Pada takaran tersebut, toksisitas dan efek samping konsumsi umbi bawang putih belum ada. Bahkan untuk wanita hamil dan menyusui, umbi bawang putih tidak menunjukkan efek negatif. Bawang putih juga tidak berefek negatif terhadap sekresi enzim pencernaan. Efek positif konsumsi bawang putih jauh lebih tinggi dibandingkan efek negatifnya. Penelitian-penelitian terbaru menunjukkan bawang putih merupakan obat mujarap untuk meningkatkan vitalitas tubuh seperti ginseng (Qattan, 2008). 
Senyawa flavonoid diketahui memiliki efek potensial sebagai anti inflamasi dan antioksidan. Senyawa flavonoid seperti flavonols, quercetin dan cathechin terbukti menghambat produksi TNF- $\alpha$ dan nitric oxide oleh lipopolisakarida dari makrofag yang teraktivasi, supresi TNF- $\alpha$ diduga melalui penghambatan aktivasi NFkB. Penghambatan TNF- $\alpha$ terjadi post transkripsi sedangkan penghambatan inducible nitric oxide synthase pada fase transkripsi. Secara in vivo kemungkinan ekstrak bawang putih (A. sativum) menghambat secara langsung produksi AGEs. Hambatan pada aktivasi NFkB akan melemahkan respon autoimun dan respon inflamasi yang pada penelitian ini menghambat proses radang pulau Langerhans (insulitis) (Qattan, 2008).

Di Indonesia, tumbuhan herbal menjadi salah satu pengobatan tradisional dan terbukti berkhasiat hepatoprotektor, contohnya curcumin yang diperoleh dari temulawak dan kunyit, filantin dan hiofilantin dari meniran, aukubin dari daun sendok, wedelolakton dari urang-aring, andrografolid dari sambiloto, minyak atsiri dari bawang putih, glycyrrhisic akar manis dan saga, krisofanol dari kelembak, dan gingerol dari jahe. Zat ini berkhasiat bekerja melindungi hepar dari kerusakan, mempercepat regenerasi hepatosit dan mengurangi keaktifan enzim siklooksigenase (Dalimartha, 2005). Zat kurkumin merangsang sel hepar membuat empedu, mencegah hepatatis dan penyakit hepar, membantu menurunkan kadar GOT dan GPT dan sebagai antihepatotoksik. Selain itu, yang dapat merangsang fungsi pankreas, menambah selera makan, berkemampuan merangsang perjalanan sistem hormon metabolisme dan fisiologi tubuh (Eissa, 2009).

\section{KESIMPULAN}

Berdasarkan hasil penelitian disimpulkan bahwa pemberian kombinasi ekstrak etanol jeringau (A. calamus), temu mangga (C. mangga), dan) bawang putih (A. sativum) sampai dosis $100 \mathrm{mg} / \mathrm{kgBB}$ tidak mempengarui kadar Enzim GPT (Glutamat Piruvat Transaminase) dan GOT (Glutamat Oksaloasetat Transaminase) hepar tikus putih (Rattus norvegicus) betina dan kadar kedua enzim tersebut masih dalam kisaran normal.

\section{DAFTAR PUSTAKA}

Byers, SL., Wiles, MV., Dunn, SL., Taft, RA. (2012). Mouse estrous cycle identification tool and images. PLoS One; 7:e35538

Chattopadhyay, I. (2004). Turmeric and Curcumin: Biological Actions and Medical Applications. Current Science. 87 (1) pp. 44-53.

Dalimartha, S. 2005. Ramuan Tradisional untuk Pengobatan Hepatitis. Jakarta: Swadaya. Eissa, F.I. dan N.A. Zidan. (2009). Haematological, biochemical and histopathological alterations induced by Abamectin and Bacillus thuringiensis in male albino rats. Journal of Basic and Applied Sciences. 3 (3) pp. 88-92.

Hayes, M. (2007). Pathophysiology Of The Liver. Usa : Saunder Company. 
Hendrajaya, K dan Dini, K. (2003). Skrining Fitokimia Limbah Rimpang Acorus calamus L. yang Telah Terdestilasi Minyak Atsirinya. Proseding Seminar dan Pameran Nasional Tumbuhan Obat Indonesia XXIII. Fakultas Farmasi Universitas Pancasila Jakarta.

Lengkong, A.B. (2013). Gambaran Histopatologik Hati Tikus Wistar Yang Diinduksi CCL4 dan diberi Air Rebusan Tanaman Cakar Ayam (Selaginella Doederleinii Hieron). Jurnal E-Biomedik. 1 (2) pp.10-18

Muchtaromah, B., Ahmad, M., Hasan, M.N, Wahyudi, D. (2018). Antioxidant and antifungal activity of Jeringau Extract of in some organic solvent. Journal Biologi el-hayah. 6(3) pp.70-78

Muchtaromah, B., Ahmad, M., Romaidi., Nazilah, L.N., Naja. N.A. (2017). Antibacterial activity of water and ethanol extract of Allium sativum, Curcuma mangga, and Acorus calamus combination. Journal of Biological Researches. 24 (1) pp.8-24

Muchtaromah, B., Ahmad, M., Sabdoningrum, E. K., Afifah, Y. M. \& Azzahra, V. L. (2017). Phytochemicals, Antioxidant and Antifungal Properties of Acorus calamus, Curcuma mangga, and Allium sativum in The Veterinary Medicine International Conference, KnE Life Sciences, 93-104. doi: 10.18502/kls.v3i6.1119.

Mudjijono, M. Herawati, Ismi. (2014). Kearifan Lokal Orang Madura Tentang Jamu Untuk Kesehatan Ibu Dan Anak. Balai Pelestarian Nilai Budaya (BPNB): Yogyakarta.

Pathak S, Ghosh K and Thakur M K. (2016). Liver Problems and Natural Cure International Journal of Science and Research 5 (10) 2319-7064

Pratiwi. (2010). Toxicity Effect of Centella asiatica L. Extract on mice (Mus musculus) Organs and Tissue. Indonesian Journal of Farmacy. 20(1) pp.10-14.

Qattan K, Thomson M, Ali M. (2008). Garlic (Allium sativum) and ginger (Zingiber officinale) attenuate structural nephropathy progression in streptozotocin induced diabetic rats. Clin Nutr and Metab. 3 (2) pp.102-104

Sagita, Ariesta Adriana, Sri Puji Aw, Saikhu A Husein. (2012). Uji Toksisitas Subkronik Polisakarida Krestin Dari Ekstrak Coriolus Versicolor Terhadap Kadar SGPT Mus Musculus L. Departemen Biologi, Fakultas Sains Dan Teknologi, Universitas Airlangga.

Sari, LORK. (2006). Pemanfaatan Obat Tradisional dengan Pertimbangan Manfaat dan Keamanannya. Majalah Ilmu Kefarmasian. 3(1) pp. 01-07.

Sjahfridi L, Aziz SN, Maheswari H, Astuti P, Suyatna FD, Nasikin M. (2011). Estrus Period Determination Of Female Rats (Rattus Norvegicus) By Fourier Transform Infrared (FTIR) Through Identification Of Reproductive Hormones 
Metabolites In Urine. International Journal of Basic and Applied Sciences. 11(3) pp.158-163.

Sukandar E Y, Tren dan Paradigma Dunia Farmasi, Industri- Klinik-Teknologi Kesehatan, disampaikan dalam orasi ilmiah Dies Natalis ITB, http://itb.ac.id/focus/focus_file/orasi-ilmiah-dies-45.pdf, diakses Januari 2016. 